\title{
STUDIES ON AUROMOMYCIN
}

\author{
Toshiaki Yamashita, Noriyuki NaOi, Takayoshi Hidaka \\ and Kryoshi Watanabe \\ Biochemical Research Laboratory, Kanegafuchi Chemical Industry Co., Ltd., \\ Takasago, Hyogo, Japan \\ Yoshiki Kumada, Tomio Takeuchi and Hamao Umezawa \\ Institute of Microbial Chemistry, Kamiosaki, Shinagawa-ku, Tokyo, Japan
}

(Received for publication October 5, 1978)

\begin{abstract}
A new antitumor antibiotic, named auromomycin, was isolated from the culture broth of Streptomyces macromomyceticus, a macromomycin-producing strain. The antibiotic was recovered from the culture filtrate by salting out with ammonium sulfate and further purified by successive application of ion-exchange chromatography on Amberlite IRA-93 ( $\mathrm{Cl}$ form) and DEAE-Sephadex (OH form), Gel filtration on Sephadex G-50 and hydrophobic chromatography on Octyl-Sepharose CL-4B. The antibiotic is an acidic polypeptide with a molecular weight of 12,500 and an isoelectric point of $\mathrm{pH} 5.4$ and consists of 16 different amino acids. It has characteristic absorption maxima at $273 \mathrm{~nm}$ and $357 \mathrm{~nm}$ in the ultraviolet spectrum and two minima at $280 \mathrm{~nm}$ and $350 \mathrm{~nm}$ in the optical rotatory dispersion spectrum. Auromomycin exhibits antibacterial activity not only against Gram-positive bacteria, but also Gram-negative bacteria. Antitumor activities of auromomycin were revealed against EH)LICH ascites carcinoma, ascites sarcoma 180, L1210 leukemia and LEWIS lung carcinoma. Aucomomycin was found to be converted into macromomycin by adsorption chromatography on Amberlite XAD.
\end{abstract}

Macromomycin, a polypeptide antibiotic produced by Streptomyces macromomyceticus ${ }^{1)}$ has been shown to be active against P388 leukemia, L1210 leukemia, B16 melanoma and LewIs lung carcinoma ${ }^{2}$. Macromomycin was reported to inhibit DNA synthesis by binding to the cell membrane by Kunimoto et $a l^{3,4)}$, Lippman ${ }^{5)}$ and Winkelhake et al. ${ }^{6)}$ Recently, Suzuki et al. ${ }^{7)}$ demonstrated that macromomycin caused inhibition of DNA synthesis and mitosis, and DNA strand scission.

During the course of our studies for the production and purification of macromomycin, one active fraction purified from the culture broth of S. macromomyceticus often had a yellow color, while macromomycin was colorless. Therefore we tried to isolate the yellow substance from the culture broth of S. macromomyceticus and obtained a new antibiotic, designated auromomycin, which showed a wider antibacterial spectrum than macromomycin.

In this paper, the production, isolation and physicochemical and biological properties of auromomycin, and the conversion of auromomycin into macromomycin are described.

\section{Fermentation}

The procedures used are similar to those employed for the production of macromomycin as described previously ${ }^{1,8)}$.

Streptcmyces macromomyceticus ATCC 29816 was inoculated into $100 \mathrm{ml}$ of a culture medium containing $1 \%$ glucose, $1 \%$ soluble starch, $1.5 \%$ soybean powder, $0.1 \%$ dipotassium phosphate, $0.3 \%$ sodium chloride, $0.1 \%$ magnesium sulfate, $0.0007 \%$ copper sulfate, $0.0001 \%$ ferrous sulfate, 
$0.0008 \%$ manganese chloride, $0.0002 \%$ zinc sulfate and $0.05 \%$ antifoamer Disfoam CC-118 (Nippon Oils and Fats Co.) in a 500-ml Sakaguchi flask. The pH was adjusted to 7.2 before sterilization. The seed inoculum was grown at $28^{\circ} \mathrm{C}$ for 2 days on a reciprocal shaker. The cultured broth $(90 \mathrm{ml})$ was transferred to 18 liters of the same medium in a jar fermentor ( 30 liters volume). The fermentation was continued under aeration of 18 liters $/ \mathrm{min}$. at $28^{\circ} \mathrm{C}$ for 3 days with stirring at $500 \mathrm{rpm}$. Maximal production of the antibiotic was attained after $60 \sim 80$ hours.

The activity of auromomycin was determined by the cylinder agar plate method using Sarcina lutea and Escherichia coli as the assay organisms. The nutrient agar medium employed for seed and base layers contained $0.6 \%$ peptone, $0.3 \%$ yeast extract, $0.15 \%$ meat extract, $0.1 \%$ glucose and $1.5 \%$ agar, and the $\mathrm{pH}$ was adjusted to 6.7 before sterilization. The diameters of the inhibition zone at the concentration of $0.5 \mathrm{mg} / \mathrm{ml}$ aqueous solution of auromomycin were about $20.0 \mathrm{~mm}$ and $19.5 \mathrm{~mm}$ against $S$. lutea and E. coli, respectively. During purification, fractions were monitored by the inhibition zone against E. coli, comparing with that of the broth filtrate.

\section{Isolation and Purification}

Sixty-four liters of the harvested broth collected from 4 jar fermentors were filtered with filter aid (Dicalite). The filtrate was saturated with ammonium sulfate and allowed to stand at $5^{\circ} \mathrm{C}$ for 4 hours. Six hundred $\mathrm{ml}$ of an aqueous solution containing $265 \mathrm{~g}$ of anhydrous sodium carbonate and immediately thereafter, $600 \mathrm{ml}$ of an aqueous solution containing $265 \mathrm{~g}$ of ferric chloride hexahydrate as a coagulant were added. The resulting precipitate was collected by continuous centrifugal separation at $5^{\circ} \mathrm{C}$ and $10,000 \mathrm{rpm}$. The precipitate $(2.2 \mathrm{~kg})$ was dissolved in 13 liters of deionized water. Insoluble material was removed by centrifugal separation and 12.1 liters of the supernatant containing auromomycin were obtained.

The solution was passed through a column $(7 \times 78 \mathrm{~cm}$, The size of column is represented by column bed size.) of Amberlite IRA-93 (3 liters, $\mathrm{Cl}$ form, Rohm and Haas Co.) to afford 13.2 liters of the effluent. The effluent was ultrafiltered by using Ultra Filter UH-1 membrane (M.W. 1,000, Toyo Filter Paper Co.) and Ultrafilter apparatus (MC-6, Bioengineering Co.) under a pressure of $3.5 \mathrm{~kg} / \mathrm{cm}^{2}$ of $\mathrm{N}_{2}$ gas to concentrate to $200 \mathrm{ml}$. The concentrate was placed on a column $(8.5 \times 88 \mathrm{~cm})$ of Sephadex G-50 (Pharmacia Fine Chemicals) and chromatographed with deionized water at a flow rate of $750 \mathrm{ml}$ /hours. The eluate was collected in fractions of $15 \mathrm{ml}$ with a fraction collector (7000 Ultrorac Fraction Collector, LKB). Based on the ultraviolet absorptions at $280 \mathrm{~nm}$ and $360 \mathrm{~nm}$ and antibacterial activities against $S$. lutea and $E$. coli of each fraction, the fractions (tube No. 163 189) containing auromomycin were combined. To $400 \mathrm{ml}$ of the active fraction obtained, $80 \mathrm{~g}$ of ammonium sulfate ( $35 \%$ saturation) were added, and the solution was applied to a column $(3 \times 42.5 \mathrm{~cm})$ of Octyl-Sepharose CL-4B (Pharmacia Fine Chemicals). The column was subsequently eluted with ammonium sulfate $35 \%$ saturation and fractions of tube No. 76 105 $(10 \mathrm{ml} /$ tube $)$ were combined. Whereby $300 \mathrm{ml}$ of a yellow fraction containing auromomycin was obtained after a peak of impure proteins. This fraction was fully desalted by Ultra Filter UH-1 and Ultrafilter apparatus (MC-4, Bioengineering Co.) and applied to a column $(3 \times 42.5 \mathrm{~cm})$ of DEAE-Sephadex A-25 ( $\mathrm{OH}$ form, Pharmacia Fine Chemicals). The column was eluted with $0.2 \mathrm{M}$ Tris- $\mathrm{HCl}$ buffer ( $\mathrm{pH} \mathrm{7.0)}$ to afford $180 \mathrm{ml}$ of the active fraction. The fraction was concentrated with Ultra Filter UH-1 to $70 \mathrm{ml}$ and thereafter subjected to column chromatography on Sephadex G-50 (2 liters, $5.6 \times 81 \mathrm{~cm})$ using deionized water as an eluting solvent. 
The eluate was collected in fractions of $15 \mathrm{ml}$ and $150 \mathrm{ml}$ of the active fraction (tube No. 63 72) were obtained and concentrated to $20 \mathrm{ml}$ by Ultra Filter UH-1. To concentrate, $2.7 \mathrm{~g}$ of ammonium sulfate was gradually added. The solution was allowed to stand in a dark place at $5^{\circ} \mathrm{C}$ for 4 days, whereupon yellow plate-like crystals of auromomycin precipitated. The mother liquor was almost colorless.

The crystals were collected on a glass filter, washed with $10 \mathrm{ml}$ of a $15 \%$ aqueous solution of ammonium sulfate and dissolved in $10 \mathrm{ml}$ of deionized water. The solution was desalted by column chromatography on Sephadex G-25 $(200 \mathrm{ml}, 2.4 \times 44 \mathrm{~cm}$, Pharmacia Fine Chemicals), and $15 \mathrm{ml}$ of the active fraction containing auromomycin was lyophilized to afford $430 \mathrm{mg}$ of yellow powder.

It was shown to be homogeneous, displaying a single band on polyacrylamide gel electrophoresis according to the method of ORSTEIN-DAvis ${ }^{9,10)}$.

\section{Physico-chemical Properties}

Aurornomycin formed plate-like yellow crystals and was obtained as a lyophilized yellow powder.

It is a weakly acidic protein, which shows an isoelectric point of $\mathrm{pH} 5.4$ as determined by electrofocusing using LKB Amploline 8101 ( $\mathrm{pH}$ of the carrier ampholite is in the range of $5 \sim 8$ ). It does not show a. definite melting or decomposition point and carbonizes completely at $260^{\circ} \mathrm{C}$. It is soluble in water but insoluble in organic solvents such as methanol, ethanol, acetone and ethyl acetate.

Auronomycin exhibits an optical rotation of $[\alpha]_{\mathrm{D}}^{20}-280$ in $1 \%$ aqueous solution. The ultraviolet absorption shows $\mathrm{E}_{1 \mathrm{~cm}}^{1 \%} 13.3$ at $273 \mathrm{~nm}$ and $\mathrm{E}_{\mathrm{ccm}}^{1 \%}$ 4.6 at $357 \mathrm{am}$ in aqueous solution, $\mathrm{E}_{1 \mathrm{~m}}^{1 \%} 14.0$ at $270 \sim 274 \mathrm{rm}$ and $\mathrm{E}_{\mathrm{com}}^{1 \%} 5.9$ at $340 \mathrm{~nm}$ in $0.01 \mathrm{~N}$ sodium hydroxide solution, and $\mathrm{E}_{\mathrm{lcm}}^{1 \%} 13.2$ at $272 \mathrm{~nm}$ and $\mathrm{E}_{1 \mathrm{em}}^{1 \%} 4.4$ at $356 \mathrm{~nm}$ in $0.01 \mathrm{~N}$ hydrochloric acid solution, with a shoulder at $290 \mathrm{~nm}$ in all three solvents. The optical rotatory dispersion spectrum measured in an aqueous solution $(2 \mathrm{mg} / \mathrm{ml})$ shows two troughs with minima at $280 \mathrm{~nm}$ and $350 \mathrm{~nm}$. The ultraviolet absorption, infrared and optical rotatory dispersion spectra are shown in Fig. 1, Fig. 2 and Fig. 3, respectively.

The antibiotic decolorizes potassium permanganate solution, gives positive FoLIN-LOWRY,

Fig. 1. Ultraviolet absorption spectra of auromomycin.

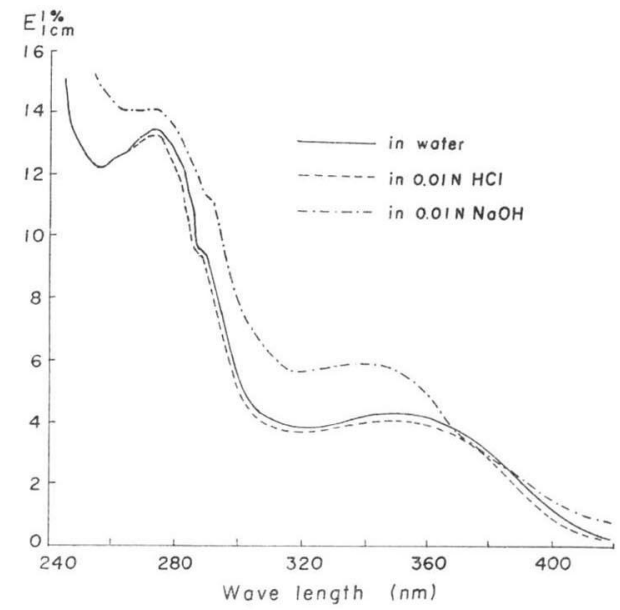

xanthoprotein, EHRLICH, biuret and ninhydrin reactions, and negative phenolsulfuric acid, anthrone, orcinol, ELSON-MORGAN and MOLISCH reactions.

The molecular weight of auromomycin was estimated to be 12,500 , since it was eluted in the same
Fig. 2. Infrared absorption spectrum of auromomycin in $\mathrm{KBr}$.

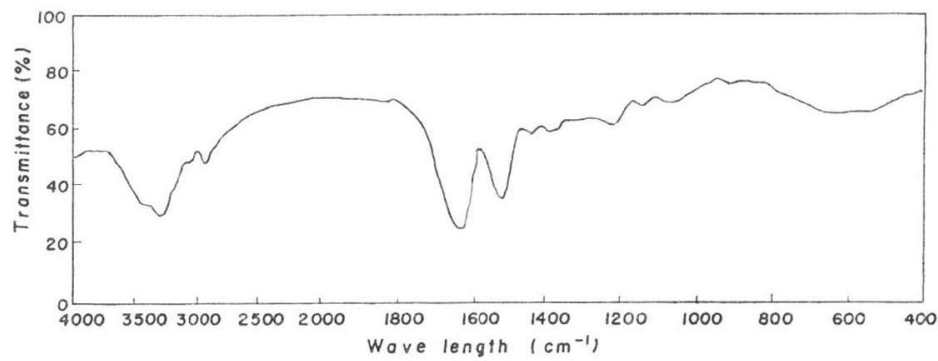


Fig. 3. Optical rotatory dispersion spectra of auromomycin, macromomycin and white powder. Measurement of the spectrum was made on aqueous solution of auromomycin $(2 \mathrm{mg} / \mathrm{ml})$, and macromomycin and white powder $(3 \mathrm{mg} / \mathrm{ml})$, respectively.

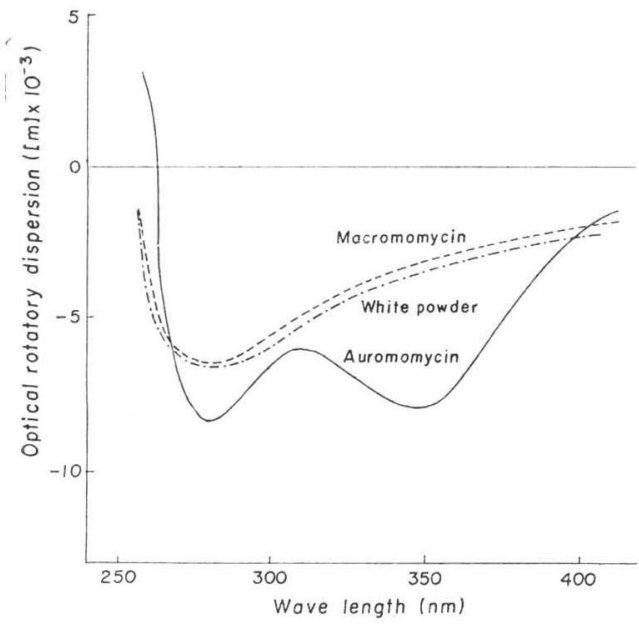

Fig. 4. Ultraviolet absorption spectra of macromomycin and white powder.

The spectra of macromomycin and white powder showed the same pattern.

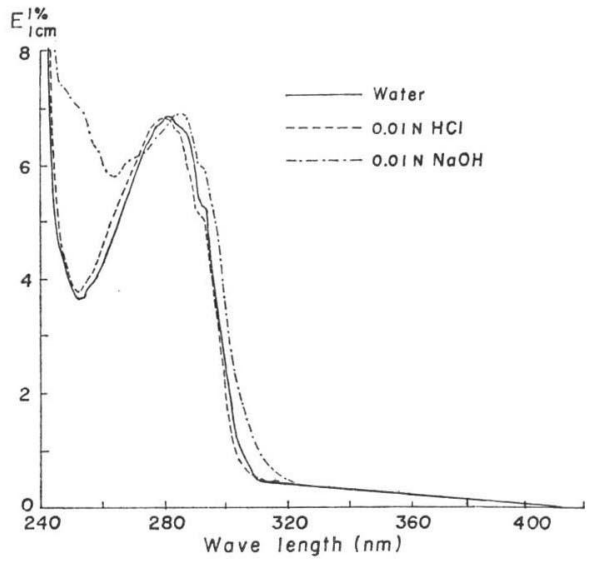

Table 1. Amino acid composition of auromomycin, macromomycin and white powder ${ }^{2}$.

\begin{tabular}{|c|c|c|c|c|c|c|}
\hline \multirow[b]{2}{*}{ Amino acid } & \multicolumn{2}{|c|}{ Auromomycin } & \multicolumn{2}{|c|}{ Macromomycin } & \multicolumn{2}{|c|}{ White powder } \\
\hline & $\begin{array}{c}\% \\
(W / W)\end{array}$ & $\begin{array}{l}\text { (No. of } \\
\text { residues) }\end{array}$ & $\begin{array}{c}\% \\
(W / W)\end{array}$ & $\begin{array}{l}\text { (No. of } \\
\text { residues) }\end{array}$ & $\begin{array}{c}\% \% \\
(W / W)\end{array}$ & $\begin{array}{l}\text { (No. of } \\
\text { residues }\end{array}$ \\
\hline Aspartic acid & 8.04 & (8) & 7.80 & (8) & 7.80 & (8) \\
\hline Threonine & 15.29 & (18) & 15.54 & (18) & 14.86 & (18) \\
\hline Serine & 7.44 & (10) & 7.73 & (10) & 7.16 & (10) \\
\hline Glutamic acid & 8.79 & (8) & 8.64 & (8) & 8.28 & (8) \\
\hline Proline & 4.26 & (5) & 4.34 & (5) & 4.32 & $(5$ or 6$)$ \\
\hline Glycine & 10.76 & (20) & 10.99 & (20) & 10.47 & (20) \\
\hline Alanine & 12.14 & (19) & 12.44 & (19) & 12.04 & (19) \\
\hline Half-cystine & 3.52 & (4) & 3.57 & (4) & 3.42 & (4) \\
\hline Valine & 14.01 & (16 or 17$)$ & 13.58 & (16) & 13.50 & (16 or 17$)$ \\
\hline Methionine & 0 & (0) & 0 & $(0)$ & 0 & $(0)$ \\
\hline Isoleucine & 2.99 & (3) & 2.79 & (3) & 2.70 & (3) \\
\hline Leucine & 4.73 & (5) & 4.55 & (5) & 4.51 & (5) \\
\hline Tyrosine & 1.51 & (1) & 1.44 & (1) & 1.42 & (1) \\
\hline Phenylalanine & 2.86 & (2) & 2.69 & (2) & 2.63 & (2) \\
\hline Tryptophan & 2.03 & (1) & 1.64 & (1) & 2.01 & (1) \\
\hline Lysine & 3.78 & ( 3 or 4$)$ & 3.71 & $(3$ or 4$)$ & 3.60 & $(3$ or 4$)$ \\
\hline Histidine & 2.47 & (2) & 2.36 & (2) & 2.28 & (2) \\
\hline Arginine & 0 & $(0)$ & 0 & $(0)$ & 0 & (0) \\
\hline
\end{tabular}

a) White powder is a polypeptide antibiotic obtained from auromomycin by Amberlite XAD-7 chromatography.

b) The proteins were hydrolyzed with $6 \mathrm{~N} \mathrm{HCl}$ at $110^{\circ} \mathrm{C}$ for 22 hours.

c) Cystine and tryptophan were measured after performic acid oxidation and barium hydroxide hydrolysis, respectively.

d) Amino acids were determined by using Hitachi Amino Acid Analyzer KLA-5 (Hitachi Ltd.). 
fractions of tube No. 29 31 ( $3 \mathrm{ml} /$ tube) as cytochrome C, when chromatographed with blue dextran 2000 (Seikagaku Kogyo Co.) and human albumin, chymotrypsinogen and cytochrome C (M.W. 45,000 25,000 anc 12,500, respectively, Boehringer Mannheim Co.) as standards on a column $(1.5 \times 90 \mathrm{~cm})$ of Sephadex G-50 $(160 \mathrm{ml})$ using $0.1 \mathrm{M}$ phosphate buffer containing $0.1 \mathrm{M} \mathrm{KCl}(\mathrm{pH} 7.0)$ as an eluting buffer at a flow rate of $35 \mathrm{ml} /$ hour. As shown in Table 1, it consists of 16 different amino acids, with methionine and arginine absent. One tryptophan residue was found in the auromomycin molecule as determined by $\mathrm{N}$-bromosuccinimide oxidation ${ }^{11}$. The reduced form of auromomycin was also shown to possess four sulfhydryl groups by $p$-chloromercuribenzoic acid titration ${ }^{12}$. This amino acid composition supports a molecular weight of approximately 12,000. The N-terminal amino acid of the antibiotic was identified as alanine by dinitrophenylation ${ }^{13)}$.

Auromomycin is relatively stable in the $\mathrm{pH}$ range of $5 \sim 9$, but loses its antibacterial activity rapidly in strong acid or alkaline solution. On standing at room temperature both the solid form and aqueous solution of auromomycin gradually lose activity. Both the solid and aqueous solution of the antibiotic are rapidly inactivated by ultraviolet irradiation.

\section{Biological Properties}

The antimicrobial spectrum of auromomycin is shown in Table 2. The antibiotic inhibited both

Table 2. Antimicrobial spectrum of auromomycin (AUR), macromomycin (MCR) and white powder (WP).

\begin{tabular}{|c|c|c|c|c|}
\hline \multirow{2}{*}{ Test organisms } & \multicolumn{3}{|c|}{$\begin{array}{l}\text { Minimum inhibitory concentration } \\
(\mu \mathrm{g} / \mathrm{ml})\end{array}$} & \multirow{2}{*}{ Media* } \\
\hline & AUR & MCR & WP & \\
\hline Staphylococcus aureus FDA 209P & 0.1 & 1.56 & 1.56 & A \\
\hline Staphylococcus aureus Smith & 0.1 & 1.56 & 1.56 & A \\
\hline Micrococcus flavus FDA16 & 0.05 & 1.56 & 0.78 & A \\
\hline Sarcina lutea PCI 1001 & 0.1 & 1.56 & 0.78 & A \\
\hline Bacillus onthracis & 0.2 & 3.12 & 3.12 & A \\
\hline Bacillus subtilis NRRL 558 & 0.2 & 1.56 & 1.56 & A \\
\hline Bacillus subtilis PCI 219 & 0.1 & 0.39 & 0.78 & A \\
\hline Bacillus cereus & 0.2 & 6.25 & 6.25 & A \\
\hline Escherichia coli NIHJ & 3.12 & $>100$ & $>100$ & A \\
\hline Escherichia coli $\mathrm{K}-12$ & 6.25 & $>100$ & $>100$ & A \\
\hline Shigella dysenteriae & 1.56 & $>100$ & $>100$ & A \\
\hline Shigella jlexneri 46JS 11811 & 6.25 & $>100$ & $>100$ & A \\
\hline Salmonella enteritidis 1891 & 25 & $>100$ & $>100$ & A \\
\hline Proteus vulgaris $\mathrm{OX}-19$ & 3.12 & $>100$ & $>100$ & A \\
\hline Proteus rettgeri GN 311 & 6.25 & $>100$ & $>100$ & A \\
\hline Proteus rettgeri GN 466 & 0.78 & $>100$ & $>100$ & A \\
\hline Serratia marcescens & 50 & $>100$ & $>100$ & A \\
\hline Pseudomonas aeruginosa $\mathrm{A} 3$ & $>100$ & $>100$ & $>100$ & A \\
\hline Klebsiella pneumoniae PCI 602 & 3.12 & $>100$ & $>100$ & A \\
\hline Mycobacterium 607 & 3.12 & $>100$ & $>100$ & B \\
\hline Mycobacterium phlei & 3.12 & $>100$ & $>100$ & B \\
\hline Candida albicans 3147 & $>100$ & $>100$ & $>100$ & $\mathrm{C}$ \\
\hline
\end{tabular}

* A: Nutrient agar medium; B: 1\% Glycerol nutrient agar medium; C: $1 \%$ Glucose nutrient agar medium. 
Table 3. Effect of auromomycin on survival time of ascites sarcoma 180 .

\begin{tabular}{l|c|c|c}
\hline $\begin{array}{c}\text { Dose } \\
(\mathrm{mg} / \mathrm{kg} / \text { day })\end{array}$ & $\begin{array}{c}\text { MST } \\
\text { (days) }\end{array}$ & $\begin{array}{c}\text { ILS } \\
(\%)\end{array}$ & $\begin{array}{c}60-\text { Day } \\
\text { survivors }\end{array}$ \\
\hline 1 & 18.5 & 13.5 & $0 / 6$ \\
0.5 & 40.7 & 149.7 & $1 / 6$ \\
0.25 & 51.0 & 212.9 & $4 / 6$ \\
0.125 & 60.0 & 268.1 & $6 / 6$ \\
0.0625 & 48.8 & 199.4 & $4 / 6$ \\
0.0313 & 46.0 & 182.2 & $3 / 6$ \\
0.0156 & 49.0 & 200.6 & $4 / 6$ \\
0.0078 & 38.7 & 137.4 & $2 / 6$ \\
- & 16.3 & 0 & $0 / 6$ \\
\hline
\end{tabular}

Ascites sarcoma $180 \quad\left(2 \times 10^{6}\right.$ cells $)$ were intraperitoneally inoculated into ddY mice. Auromomycin was dissolved in physiological saline and intraperitoneally injected once daily for 5 days, starting 24 hours after tumor inoculation.

MST: Mean survival time. ILS: Increase in life span.

Table 5. Effect of auromomycin on survival time of L1210 leukemia.

\begin{tabular}{l|c|c|c}
\hline $\begin{array}{c}\text { Dose } \\
(\mathrm{mg} / \mathrm{kg} / \text { day })\end{array}$ & $\begin{array}{c}\text { MST } \\
\text { (days) }\end{array}$ & $\begin{array}{c}\text { ILS } \\
(\%)\end{array}$ & $\begin{array}{c}\text { 30-Day } \\
\text { survivors }\end{array}$ \\
\hline 1 & 10.3 & 21.2 & $0 / 6$ \\
0.5 & 12.2 & 43.5 & $0 / 6$ \\
0.25 & 12.7 & 49.4 & $0 / 6$ \\
0.125 & 11.5 & 35.3 & $0 / 6$ \\
0.0625 & 11.5 & 35.3 & $0 / 6$ \\
0.0313 & 11.0 & 29.4 & $0 / 6$ \\
0.0156 & 9.7 & 14.1 & $0 / 6$ \\
- & 8.5 & 0 & $0 / 6$
\end{tabular}

L1210 leukemia $\left(1 \times 10^{5}\right.$ cells) were intraperitoneally inoculated into $\mathrm{BDF}_{1}$ mice. Auromomycin was dissolved in physiological saline and intraperitoneally injected once daily for 5 days, starting 24 hours after tumor inoculation.

MST: Mean survival time. ILS: Increase in life span.

Gram-positive and Gram-negative bacteria, although it did not inhibit Pseudomonas aeruginosa. Also, it did not effect Candida albicans.

Treatment with proteolytic enzymes such as trypsin, chymotrypsin, papain, thermolysin and pronase ( $\mathrm{pH} 7.5,30^{\circ} \mathrm{C}$ for 1 hour) failed to reduce antibacterial activity.

As shown in Tables 3 and 4, auromomycin was markedly active against ascites sarcoma 180 and
Table 4. Effect of auromomycin on survival time of EHRLICH ascites carcinoma.

\begin{tabular}{l|c|c|c}
\hline $\begin{array}{c}\text { Dose } \\
(\mathrm{mg} / \mathrm{kg} / \text { day })\end{array}$ & $\begin{array}{c}\text { MST } \\
\text { (days) }\end{array}$ & $\begin{array}{c}\text { ILS } \\
(\%)\end{array}$ & $\begin{array}{c}\text { 60-Day } \\
\text { survivors }\end{array}$ \\
\hline 1 & 25.2 & 65.8 & $0 / 6$ \\
0.5 & 43.7 & 187.5 & $3 / 6$ \\
0.25 & 59.0 & 288.2 & $5 / 6$ \\
0.125 & 55.3 & 263.8 & $4 / 6$ \\
0.0625 & 51.3 & 237.5 & $4 / 6$ \\
0.0313 & 45.0 & 196.1 & $3 / 6$ \\
0.0156 & 39.5 & 159.9 & $3 / 6$ \\
0.0078 & 23.7 & 55.9 & $1 / 6$ \\
- & 15.2 & 0 & $0 / 6$ \\
\hline
\end{tabular}

EHRLICH ascites carcinoma $\left(2 \times 10^{6}\right.$ cells $)$ were intraperitoneally inoculated into ddY mice. Auromomycin was dissolved in physiological saline and intraperitoneally injected once daily for 5 days, starting 24 hours after tumor inoculation.

MST: Mean survival time. ILS: Increase in life span.

Table 6. Comparison of the antitumor activity of auromomycin, macromomycin and neocarzinostatin against LEWIS lung carcinoma subcutaneously implanted.

\begin{tabular}{l|l|l|l|r|c}
\hline Agents & $\begin{array}{c}\text { Dose } \\
(\mathrm{mg} / \mathrm{kg} / \\
\text { day) }\end{array}$ & Route & $\begin{array}{c}\text { MST } \\
\text { (days) }\end{array}$ & $\begin{array}{c}\text { ILS } \\
(\%)\end{array}$ & $\begin{array}{c}90-\text { Day } \\
\text { survivors }\end{array}$ \\
\hline AUR & 0.25 & ip & 20.8 & -37.9 & $0 / 6$ \\
& 0.0625 & ip & 35.7 & 6.6 & $0 / 6$ \\
MCR & 3.13 & ip & 26.8 & -20.0 & $0 / 6$ \\
& 0.78 & ip & 33.5 & 0 & $0 / 6$ \\
NCS & 0.25 & ip & 29.5 & -11.9 & $0 / 6$ \\
& 0.0625 & ip & 31.2 & -6.9 & $0 / 6$ \\
\hline AUR & 0.25 & sc & 32.0 & -4.5 & $0 / 6$ \\
& 0.0625 & sc & 50.3 & 50.1 & $2 / 6$ \\
MCR & 3.13 & sc & 70.5 & 110.4 & $3 / 6$ \\
& 0.78 & sc & 63.7 & 90.1 & $3 / 6$ \\
NCS & 0.25 & sc & 65.5 & 95.5 & $3 / 6$ \\
& 0.0625 & sc & 36.5 & 9.0 & $0 / 6$ \\
\hline
\end{tabular}

$\mathrm{BDF}_{1}$ mice were subcutaneously inoculated with $2 \times 10^{6}$ cells of LewIs lung carcinoma. Auromomycin (AUR), macromomycin (MCR), and neocarzinostatin (NCS) were dissolved in physiological saline and were injected intraperitoneally (ip) or subcutaneously (sc) at the site of tumor inoculation once daily for 10 days, starting 24 hours after tumor inoculation.

MST: Mean survival time. ILS: Increase in life span. 
EHRLICH ascites carcinoma in a dose range of $0.0078 \sim 0.5 \mathrm{mg} / \mathrm{kg} /$ day when administered intraperitoneally once daily for 5 days, starting one day after umor inoculation. Most of the mice treated wi1h $0.0156 \sim 0.25 \mathrm{mg} / \mathrm{kg} /$ day survived for more thar 60 days. As shown in Table 5, it was also active against L1210 leukemia in a dose range of $0.03 \sim 0.5 \mathrm{mg} / \mathrm{kg} /$ day when administered intraperitcneally once daily for 5 days, starting 24 hours after tumor inoculation. The maximal increase of life span was about $49 \%$.

The antitumor activity of auromomycin was compared with macromomycin and neocarzinostatin (Ya nanouchi Pharmaceutical Co.) against LEwIs lung carcinoma as shown in Table 6 and Table 7. All of the drugs were inactive when administered intraperitoneally against LEWIS lung carcinoma implanted subcutaneously, but were active when administered subcutaneously at the site of tumor inoculation (Table 6). In the latter case macromomycin was more effective than auromomycin and neocarzinostatin. As shown in Table 7, a single intravenous injection of auromomycin possessed marked activity against LEWIS lung carcinoma implanted intravenously. Treatment with $1.5 \mathrm{mg} / \mathrm{kg}$ of auromomycin resulted in survival of all the mice for over 60 days after tumor inoculation. Macromomycin and neocarzinostatin were also effective but their activity was less than that of auromomycin.

The $\mathbf{L} \mathbf{D}_{50}$ by a single intravenous injection of auromomycin to ddY mice was $3 \mathrm{mg} / \mathrm{kg}$.

\section{Conversion of Auromomycin into Macromomycin}

A variety of methods such as adsorption chromatography using silica gel, alumina and Amberlite XAD (Rchm and Haas Co.), ion-exchange chromatography, treatment with acid, alkaline or heat, and irradiation with ultraviolet light were studied for the conversion of auromomycin into macromomycin. Consequently, adsorption chromatography on Amberlite XAD-7 was found to be most suitable. The procedures used are as follows:

Auromomycin $(500 \mathrm{mg}$ ) was dissolved in $200 \mathrm{ml}$ of an $8 \%$ aqueous solution of ammonium sulfate. The solution was applied to a column $(3 \times 21 \mathrm{~cm})$ of Amberlite XAD-7 $(150 \mathrm{ml})$. The column was washed with $200 \mathrm{ml}$ of the $8 \%$ aqueous solution of ammonium sulfate at a flow rate of $450 \mathrm{ml} / \mathrm{hour}$ and followed immediately by elution with $30 \%$ ethanol collecting fractions of $5 \mathrm{ml}$. The fractions of tube No. $13 \sim \$ 2$ which showed antibacterial activity against $S$. lutea and strong ultraviolet absorption at $280 \mathrm{~nm}$ were combined to afford $100 \mathrm{ml}$. The fraction obtained was concentrated to $60 \mathrm{ml}$ using a rotary evaporator at $40^{\circ} \mathrm{C}$ under reduced pressure to remove ethanol. The concentrate was placed on a column $(5.6 \times 81 \mathrm{~cm})$ of Sephadex G-50 (2 liters), and developed with deionized water to obtain $150 \mathrm{ml}$ of an active fraction. This fraction was lyophilized to yield $140 \mathrm{mg}$ of a white powder.

The physicochemical and biological properties of the white powder obtained were compared 
with those of auromomycin and macromomycin (authentic sample produced by Kanegafuchi Chemical Ind., Co.). The same 16 amino acids were detected in the hydrolysate of the powder as in hydrolysates of auromomycin and macromomycin, as shown in Table 1. Similarly, the mobility of the protein on a column of Sephadex G-50 was similar to that of cytochrome C (M.W. 12,500) under the same condition as the molecular weight of auromomycin was determined, suggesting that its molecular weight was approximately 12,500. Its isoelectric point as measured with LKB Ampholine 8101 was also found to be $\mathrm{pH}$ 5.4. By contrast, as shown in Fig. 4, the ultraviolet absorption showed $\mathrm{E}_{1 \mathrm{~cm}}^{1 \%}$

Fig. 5. Elution patterns from chromatography of the mixture of auromomycin and macromomycin, and white powder alone on Octyl-Sepharose CL-4B.

One hundred mg of auromomycin and $100 \mathrm{mg}$ of macromomycin were dissolved in $30 \mathrm{ml}$ of first eluting buffer ( $0.1 \mathrm{~mm}$ phosphate buffer, $\mathrm{pH} 7.0$, of $40 \%$ saturation with ammonium sulfate) and mixed. The solution was added to a column $(2 \times 38 \mathrm{~cm})$ of Octyl-Sepharose CL-4B $(120 \mathrm{ml})$.

The column was eluted with the same buffer until peak A was eluted, which required approximately $600 \mathrm{ml}$ of the first eluting buffer, and thereafter, with second eluting buffer $(0.1 \mathrm{~mm}$ phosphate buffer, $\mathrm{pH} 7.0$, of $20 \%$ saturation with ammonium sulfate) until peak $B$ was eluted. The volume of a fraction collected by a fraction collector was $10 \mathrm{ml}$.

The absorbance at $280 \mathrm{~nm}(\bigcirc)$ and the antibacterial activities against $S$. lutea $(\triangle)$ and $E$. coli $(\diamond)$ of the fractions in the eluate were measured. Independently, one hundred and fifty $\mathrm{mg}$ of white powder obtained in the present investigation was dissolved in $30 \mathrm{ml}$ of the first eluting buffer, and chromatographed with the same procedures as described above. The absorbance at $280 \mathrm{~nm}$ () and the antibacterial activities against $S$. lutea (A) and E. coli (no activity showed) were similarly measured.

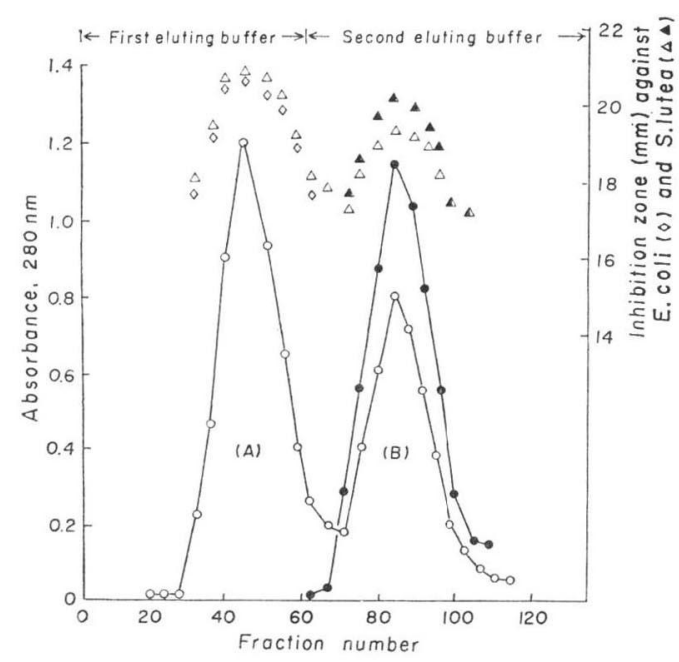

6.7 at $280 \mathrm{~nm}$ in aqueous solution, $\mathrm{E}_{1 \mathrm{~cm}}^{1 \%} 6.7$ at $280 \sim 284 \mathrm{~nm}$ in $0.01 \mathrm{~N}$ sodium hydroxide solution, and $\mathrm{E}_{\mathrm{lcm}}^{1 \%} 6.7$ at $280 \mathrm{~nm}$ in $0.01 \mathrm{~N}$ hydrochloric acid solution, with a shoulder at $290 \mathrm{~nm}$ in all three solvents. It is noted that the characteristic maximum at $340 \sim 360 \mathrm{~nm}$ in the ultraviolet absorption spectrum of auromomycin disappears in that of the powder and the maximum shifts from $273 \mathrm{~nm}$ to $280 \mathrm{~nm}$ with the

Table 8. Comparison of the characteristic properties between auromomycin, macromomycin and white powder.

\begin{tabular}{|c|c|c|}
\hline & Auromomycin & $\begin{array}{l}\text { Macromomycin } \\
\text { and white } \\
\text { powder }\end{array}$ \\
\hline $\begin{array}{l}\text { Property of puri- } \\
\text { fied product }\end{array}$ & $\begin{array}{l}\text { yellow plate- } \\
\text { like crystals }\end{array}$ & white powder \\
\hline $\begin{array}{l}\text { Molecular weight } \\
\text { (the method of } \\
\text { gel filtration) }\end{array}$ & 12,500 & 12,500 \\
\hline Isoelectric point & $\mathrm{pH} 5.4$ & $\mathrm{pH} 5.4$ \\
\hline $\begin{array}{l}\text { No. of constitutive } \\
\text { amino acids }\end{array}$ & $\begin{array}{l}16 \\
\text { (Met and Arg } \\
\text { are absent) }\end{array}$ & $\begin{array}{l}16 \\
\text { (Met and Arg } \\
\text { are absent) }\end{array}$ \\
\hline $\begin{array}{l}\lambda_{\max }\left(\mathrm{E}_{1 \mathrm{~cm}}^{1 \%}\right) \text { in the } \\
\text { UV absorption } \\
\text { spectrum } \\
\text { (in water) }\end{array}$ & $\begin{array}{l}273 \mathrm{~nm}(13.3) \\
\text { and } 357 \mathrm{~nm} \\
(4.6)\end{array}$ & $280 \mathrm{~nm}(6.7)$ \\
\hline $\begin{array}{l}\text { Minimum in } \\
\text { ORD }^{a} \text { spectrum }\end{array}$ & $\begin{array}{l}280 \mathrm{~nm} \text { and } \\
350 \mathrm{~nm}\end{array}$ & $280 \mathrm{~nm}$ \\
\hline $\begin{array}{l}\text { Antibacterial } \\
\text { activity }\end{array}$ & $\begin{array}{l}\text { Inhibition of } \\
\text { Gram-positive } \\
\text { and Gram- } \\
\text { negative } \\
\text { bacteria }\end{array}$ & $\begin{array}{l}\text { Inhibition of } \\
\text { Gram-positive } \\
\text { bacteria }\end{array}$ \\
\hline $\begin{array}{l}\text { Antitumor activity: } \\
\text { effective dose } \\
\text { (mg/kg/day) } \\
\text { against L1210 }\end{array}$ & $\begin{array}{l}0.03 \sim 0.5 \mathrm{mg} / \\
\mathrm{kg} / \mathrm{day}\end{array}$ & $\begin{array}{l}0.2 \sim 6 \mathrm{mg} / \\
\mathrm{kg} / \mathrm{day}\end{array}$ \\
\hline and $\left.\max . \mathrm{ILS}^{\mathrm{b}}\right)(\%)$ & $49 \%$ & $>70 \%$ \\
\hline $\begin{array}{l}\mathrm{LD}_{50} \text { (iv injection } \\
\text { to mice) }\end{array}$ & $3 \mathrm{mg} / \mathrm{kg}$ & $35 \mathrm{mg} / \mathrm{kg}$ \\
\hline $\begin{array}{l}\text { Affinity on Octyl- } \\
\text { Sepharose CL-4B }\end{array}$ & weaker & stronger \\
\hline
\end{tabular}

a) ORD: Optical rotatory dispersion.

b) ILS: Increase in life span. 
conversion of auromomycin into the white powder i.e., macromomycin (Fig. 1,4). As shown in Fig. 3, the optical rotatory dispersion spectrum of the powder showed only a single trough with a minimum at $280 \mathrm{~nm}$ whereas the minimum at $350 \mathrm{~nm}$ in auromomycin disappeared. The ultraviolet absorption and the optical rotatory dispersion spectra of the powder agreed completely with those of macromomycin. There was no difference in the infrared spectra between authentic auromomycin, macromomycin and the powder. As observed with macromomycin, the powder inhibited Grampositive bacteria but exhibited no activity against Gram-negative bacteria, as shown in Table 2 . It was active against L1210 leukemia when $0.2 \sim 6 \mathrm{mg} / \mathrm{kg} /$ day was administered intraperitoneally once daily for 5 consecutive days starting 24 hours after the tumor inoculation. The maximal increase of life span was over $70 \%$. The $\mathrm{LD}_{50}$ after a single intravenous injection administered to mice was $35 \mathrm{mg} / \mathrm{kg}$. Fig. 5 shows the elution pattern from chromatography of the mixture of auromomycin and macromomycin and the white powder alone on a column $(2 \times 38 \mathrm{~cm})$ of Octyl-Sepharose CL-4B $(120 \mathrm{ml})$. Fractions $(10 \mathrm{ml})$ were collected with the elution of two peaks $(\mathrm{A}$ and $\mathrm{B})$. The first peak (A) and the second peak (B) contained auromomycin and macromomycin, respectively, which were confirmed by examining the antibacterial activities of the fractions against $S$. lutea and E. coli. These auromomycin and macromomycin can be separated by Octyl-Sepharose CL-4B chromatography and the powder exhibits the same behavior as macromomycin.

The characteristic differences in physicochemical and biological properties between auromomycin, macromornycin and white powder obtained in the present investigation are summarized in Table 8 . These properties of the white powder differed from those of auromomycin and were the same as those of macromomycin which were determined at the same time and reported previously ${ }^{1,8,14)}$. Therefore, it was identified as macromomycin.

\section{Discussion}

While carrying out studies for the purification of macromomycin from culture filtrates of Streptomyces macromomyceticus ATCC 29816, we often experienced that lyophilized macromomycin powders purified by conventional procedures ${ }^{1,8)}$ such as salting out with ammonium sulfate, gel filtration and ion exchange, had a yellow color. The fact suggested that the strain could produce macromomycin and at the same time another antibiotic. It had been difficult to separate macromomycin and auromomycin, but we succeeded in their separation using Octyl-Sepharose CL-4B (Fig. 5).

Auromomycin forms plate-like yellow crystals, but macromomycin is not crystallized. Auromomycin is very similar to macromomycin in the following properties: molecular weight, isoelectric point and constitutive amino acids. But as summarized in Table 8, auromomycin is clearly different from macromomycin in the following properties: ultraviolet absorption spectrum, optical rotatory dispersion spectrum, antibacterial activity, effective dose range against L1210 leukemia and the maximal increase in life span, and acute toxicity to mice. Auromomycin is also observed to be different from neocarzinostatin ${ }^{15}$. For example, neocarzinostatin does not contain histidine which is present in auromomycin, but contains arginine which is absent in auromomycin. The isoelectric point of neocarzinostatin is $\mathrm{pH} 3.5$, whereas that of auromomycin is $\mathrm{pH} 5.4$. Neocarzinostatin does not inhibit Gram-negative bacteria but auromomycin inhibits these bacteria.

Auromomycin was confirmed to be converted into macromomycin by adsorption chromatography on Amberlite XAD-7. This method is useful for preparation of macromomycin. The application of this chromatography to culture filtrates of Streptomyces macromomyceticus which contains both auromomycin and macromomycin can also give homogeneous macromomycin. The mechanism of the conversion is not well defined, except the chromophore present in the auromomycin molecule having a maximum ultraviolet absorption at $350 \sim 360 \mathrm{~nm}$ is removed by Amberlite XAD-7 chromatography. 


\section{References}

1) Chimura, H.; M. Ishizuka, M. Hamada, S. Hori, K. Kimura, J. Iwanaga, T. Takeuchi \& H. Umezawa: A new antibiotic, macromomycin, exhibiting antitumor activity and antimicrobial activity. J. Antibiotics 21: $44 \sim 49,1968$

2) Lippman, M. M.; W. R. Laster, B. J. Aвbott, J. Venditti \& M. Baratta: Antitumor activity of macromomycin B (NSC-170105) against murine leukemia, melanoma and lung carcinoma. Cancer Res. 35: $939 \sim 945,1975$

3) Kunimoto, T.; M. Hori \& H. Umezawa: Reversible binding of macromomycin, a macromolecular peptide antibiotic, to cell membranes. J. Antibiotics 24: 203 205, 1971

4) Kunimoto, T.; M. Hori \& H. Umezawa: Macromomycin, an inhibitor of the membrane function of tumor cells. Cancer Res. 32: $1251 \sim 1256,1972$

5) Lippman, M. M.: In vitro studies on macromomycin (NSC-170105). Effects on cultured TA3Ha and L1210 cells. Cancer Chemoth. Rept. 58: 181 187, 1974

6) Winkelhake, J. L. \& F. L. A. Buckmire: Radioimmune assay and characteristics of antibodies to macromomycin (NSC-170105). Cancer Res. 37: 1197 1204, 1977

7) Suzuki, H.; T. Nishimura, K. Muto \& N. Tanaka: Mechanism of action of macromomycin: DNA strand scission, inhibition of DNA synthesis and mitosis. J. Antibiotics 31: 875 883, 1978

8) Yamashita, T.; N. Naoi, K. Watanabe, T. Takeuchi \& H. Umezawa: Further purification and characterization of macromomycin. J. Antibiotics 29: 415 423, 1976

9) Orstern, L.: Disc electrophoresis. I. Background and theory. Ann. New York Acad. Sci. 121: $321 \sim$ 349,1964

10) Davis, B. J.: Disc electrophoresis. II. Method and application to human serum proteins. Ann. New York Acad. Sci. 121: 404 427, 1964

11) Spande, T.F. \& B. WitKoP: Determination of the tryptophan content of protein with N-bromosuccinimide. Methods Enzymol. 11: 498 506, 1967

12) BOYER, P. D.: Spectrophotometric study of the reaction of protein sulfhydryl groups with organic mercurials. J. Am. Chem. Soc. 76: 4331 4337, 1954

13) SAnger, F.: Free amino groups of insulin. Biochem. J. 39: 507 515, 1945

14) Im, W. B.; C. Chiang \& R. Montgomery: Studies on macromomycin, an antitumor protein. J. Biol. Chem. 253: 3259 3264, 1978

15) Maeda, H.; K. Kumagai \& N. Ishida: Characterization of neocarzinostatin. J. Antibiotics, Ser. A 19: $253 \sim 259,1966$ 